\title{
AN ANALYSIS OF BROKERAGE RECOMMENDATIONS FOR THE BIGGEST COMPANIES OF WIG20
}

Keywords: recommendations, capital market, brokerage house.

\section{J E L Classification: G24.}

\begin{abstract}
The aim of the article is an analysis of stock recommendations. The article presents the measures that can be used for estimating the effectiveness of recommendations. The biggest companies of WIG20, the basic index of the Warsaw Stock Exchange, were analysed. Almost 600 recommendations issued by 40 brokerage offices and houses in the years 2010-2015 were analysed. Apart from the analysis of the rates of return realized on the basis of stock recommendations, attention was drawn to the issue of the investment risk.
\end{abstract}

\section{IIITRODUCTION}

Choosing the instruments for the investment portfolio is for every investor one of the most crucial phases of the investment process towards achieving the highest rate of return. The decisions of this kind may be taken as a consequence of a detailed analysis of the market and instruments on the basis of the historical data. Less experienced investors can in turn rely on opinions of experts, including opinions of stock market analysts preparing recommenda-

Date of submission: May 25, 2017; date of acceptance: June 16, 2017.

* Contact information: zbyszekdre@poczta.onet.pl, WSB University in Toruń, Młodzieżowa 31a, 87-100 Toruń, Poland, phone: +48 566609241. 
tions on future changes in prices of specific financial instruments. The article aims at presenting the methods used for assessing the effectiveness of recommendations and their application in the analysis of recommendations issued by brokerage offices and houses for the biggest companies of the Warsaw Stock Exchange.

In the literature, we find a number of analyzes of recommendations concerning their effectiveness, where the main focus is on their realization. When analyzing the investment risk, we should largely focus on unrealized recommendations, as they contribute to the losses of investors who rely on recommendations from brokerage houses. That is why, the article will discuss the number of session days needed to complete the recommendation, the maximum loss for unrealized recommendations, and the standard deviation of the daily rate of return for the recommended companies before and after the recommendation.

Among recommendations the following can be found: reports, analyses or other types of information recommending or suggesting, directly or indirectly, specific investment behaviour relating to one or more financial instruments or an issuer of financial instruments. Opinions on matters relating to the current or future value or price of financial instruments are also counted as recommendations.

Recommendations can also be made by an independent analyst or a dedicated specialised recommending company, as well as by other institutions such as banks or brokerage houses.

A recommendation should include the following information:

- the company (its name) and the registered place of the entity responsible for drawing up a recommendation,

- the name and surname of the person making a recommendation,

- the date of making,

- providing a list of those for whom a recommendation has been made,

- a list of recommendations concerning a given financial instrument presented by a given recommending person in the last 6 months,

- indicating strong and weak sides of methods used in financial instruments pricing.

A recommendation should include facts on which the recommendation is based. Sources of information constituting the basis of the issued opinion shall also be given and the credibility of the sources should be referred to. Most of all, a recommendation should include predictions, forecasts or price projections 
concerning behaviour of a financial instrument as well as significant assumptions adopted or made during drawing up a recommendation. In a typical recommendation characteristics of the industry a company operates in and the most important information about a company, its characteristics and basic indicators of a financial analysis can be found. However, the target price constituting a share price forecast in the future is the most crucial part.

A recommending person should indicate all connections and circumstances that could influence the objectivity of drawn up recommendations, in particular information concerning a recommending person's capital involvement in financial instruments being the subject of a recommendation or the existence of a significant conflict of interests between a recommending person and an issuer of financial instruments being the subject of a recommendation.

Recommendations can be divided into three main categories:

- buy recommendations,

- neutral (hold) recommendations,

- sell recommendations.

Table 1. Types of recommendations

\begin{tabular}{|l|l|l|}
\hline \hline \multicolumn{1}{|c|}{ Buy recommendations } & Neutral recommendations & \multicolumn{1}{|c|}{ Sell recommendations } \\
\hline \hline Accumulate & Neutral & Reduce \\
Buy & Market Underperform & Sell \\
Overweight & Hold & Underweight \\
& Value & \\
& Equal-weight & \\
& Market Overperform & \\
&
\end{tabular}

S o u r ce: own study.

Table 1. presents examples of buy, neutral and sell recommendations. The multitude of terms may cause confusion among investors as to the importance of individual terms. Buy and sell recommendations, which suggest buying or selling a financial instrument precisely, are the most precise ones. In the case of neutral recommendations, their elements, for example those concerning the target price, should be gone through first before evaluating their suitability. It is also important to remember that in the case of so-called short sell, a buy recommendation may constitute a suggestion of closing a short position in a given instrument, while a sell recommendation constitutes a suggestion of opening a short position. 
According to the concept of market high efficiency, a recommendation should be kept secret until it becomes available, otherwise the persons who obtain such knowledge earlier (insiders) would have an advantage over outsiders, which would lead to information asymmetry. Institutions issuing recommendations should apply appropriate procedures in this scope consisting of, first of all, a limited access to a recommendation being drawn up for employees dealing with offering, selling or buying financial instruments.

In many cases, recommendations provide an additional argument to taking a particular investment decision. Less experienced investors, when using a recommendation, can rely on expertise and experience of analysts representing particular financial institutions. More advanced investors, who evaluate risk and benefits of an investment in particular instruments by themselves, can also rely on recommendations, which in this case constitute one of many sources of information.

Therefore, it seems crucial that recommendations issued by financial institutions (banks, brokerage offices and houses) should be reliable and honest. It is reasonable to verify the effectiveness of those recommendations generally manifesting in their efficiency or accuracy. A recommendation should encourage an investor to buy (buy recommendation) or to sell (sell recommendation) a given financial instrument. Recommendations largely base on listed companies valuation and on macroeconomic indicators, they are therefore connected with so-called fundamental analysis. If, through valuation, the value of a company's stocks is set at the level $V$, then recommendations should be issued in accordance with the following algorithm:

$$
\begin{aligned}
& \text { if } \frac{V}{P_{c}}>1=>\text { buy recommendation } \\
& \text { if } \frac{V}{P_{c}}=1=>\text { hold recommendation } \\
& \text { if } \frac{V}{P_{c}}<1=>\text { sell recommendation }
\end{aligned}
$$

where:

$\mathrm{V}$ - valuation of stock price,

$\mathrm{P}_{\mathrm{c}}$ - current stock price. 
A recommending person should base the valuation on at least two methods. The ones the most often used in this area are the following: the Discounted Cash Flow method (DCF) and the comparative method (Dechow, Kothari \& Watts, 1998). A recommendation thus constitutes analysts' opinion regarding improper valuation of a given financial instrument performed by the market. In accordance with analysts' opinion, a given instrument can be underestimated and therefore an increase in its market value is forecast (buy recommendation) or overvalued and then it constitutes a subject of sell recommendation. Analysts and institutions issuing recommendations have in many cases an easier access to information on companies, which is not always the preserve of institutional investors. Getting acquainted with a recommendation can therefore be a way of reducing information asymmetry.

\section{LITERATURE REVIEW}

The first studies on evaluation of recommendations can be found in Cowles work from 1933. He came to the conclusion that basing one's investment policy on recommendations did not lead to generating above average rates of return. Among contemporary authors, Womack's study from 1996 should be drawn attention to. He analysed recommendations on the American stock market. He paid attention to the influence of listing of shares from the past on issued recommendations and noted that among recommendations those concerning the purchaser prevail. Ertimur (2010) came to a similar conclusion analysing the American stock market in the years 1994-2006. The vast majority of buy recommendations was also confirmed in the studies of Papakroni, Barber (2001), Jagadeeshi (2004) or Loh and Mian (2006). Studies on the importance of recommendations often include conclusions that brokerage offices and houses (as the supply side of the market) are more inclined to issue buy recommendations that sell recommendations. The willingness to gather clients is a natural thing, which results in greater interest in recommendations which can lead to purchasing specific instruments through brokerage offices and houses issuing those recommendations.

According to the current literature, most analysts are preparing rather optimistic broker recommendations. For example, Womack (1996) notes that in the period of 1989-1991 the US issued 7 times more buying recommendations than sales, which explains the reluctance of specialists to give negative reports. Ertimur (2010) estimates that between 1994 and 2006 approximately 57\% of 
all recommendations in the United States were in the "buy" category. At the same time the sales recommendation was included in only $6 \%$ of the reports. Papakroni (2012) calculated in turn that during the 1993-2011 period, about $68 \%$ of US recommendations were buy ones, while only $1 \%$ sold ones. Similar observations have also been made by Barber et al. (2001), Jagadeeshi et al. (2004) and Lohi Mian (2006).

Jegadeesh and Kim (2006) carried out the research on effectiveness of recommendations in G7 countries. They indicated that stock prices on the market on the day of publication of the recommendation, and on subsequent days, responded in accordance with the recommendations contained therein. In the period up to 6 months, stock prices generally followed in a direction consistent with recompilation. This is particularly evident in the most developed countries like the United States and Japan.

Also, analyzes conducted by Ryan and Taffler (2006) in the UK have confirmed that prices on stock exchanges are changing in line with recommendations from both the date of issue and the next few months. They also showed stronger market reactions to sales orders than buy orders reactions, and also showed that the response of investors to recommendations is stronger for smaller companies.

Other analyzes conducted on the US market indicate, however, that stock prices of companies that issued buy recommendations generated yields better than market prices of just $2 \%$. These studies also showed that after the recommendation, share prices of those companies gained 3\% immediately after they were published. Research has suggested that transaction costs could outweigh the potential benefits of investing in these shares (Zaremba, 2010).

In the Polish literature the issue of brokerage recommendations evaluation was dealt with by, among others, Biedrzyński (2008), Czyżycki, Klóska (2010), Konopko, Kokolus (2012) or Zaremba, Konieczka (2014). All the authors drew similar conclusions in their analyses indicating low effectiveness of this kind of analysts' forecasts.

Konopko and Kokolus (2012) calculated that in 2010-2011 only 47\% of the recommended companies reached target prices within 6 months after the publication of the report. Biedrzyński (2008) noted that only 57\%, in the case of shares for which analytical reports were issued, prices changed in the direction predicted by analysts. The regression analysis carried out by Czyżycki, Klóska (2010) is also a relatively low estimate of prognostic properties of brokerage recommendations. 
Analyzes conducted by Adamczyk (2010) have shown that analysts in the recommendations correctly evaluate the direction in which stock prices follow. However, detailed studies have shown that if a market return is taken as a benchmark, only one recommendation would be effective. In the cited study, the effectiveness of individual brokerage offices was also assessed.

Kowalke (2012) conducted a study on the suitability of recommendations based on target prices. They showed that only in 30\% of recommendations market prices deviated from internal values by less than $10 \%$.

The analyzes carried out by Boczkowski (2008) draw attention to another aspect related to the publication of recommendations, namely the issue of relatively high number of "buy" recommendations by brokerage offices during the unfavorable market conditions. Of the 131 analyzed recommendations during the downturn, 55 recommended buying shares, while only 15 sold them. The following months showed that most of the buy recommendations were wrong.

On the other hand, Prusak (2015) presented the issue of recommendation comprehensively. Except for regulatory matters, the author primarily tried to answer the question of whether stock exchange recommendations might add value to prospective investors.

\section{SAMPle SElEction ANd Descriptive Statistics}

Recommendations issued for shares of 5 biggest companies of WIG20 index have been analysed. WIG20 index represents twenty biggest and most liquid companies on the Warsaw Stock Exchange (GPW) Main Market. WIG20 is a price index, which means that when it is calculated, only the prices of the indexed transactions are taken into account, and dividend income is not taken into consideration. No more than 5 companies from the same stock market sector can participate in WIG20 index.

Among the 5 biggest WIG20 index companies two banks, PKO BP and PEKAO, KGHM mining and metallurgy company, PKN Orlen fuel group and the biggest Polish insurance company - PZU can be found. The afore-mentioned companies represent over $55 \%$ of the share in WIG20 index (figure 1).

KGHM Polska Miedź (KGHM Polish Copper) was established in 1991 in place of the previous Polish State Mining and Metallurgical Combine in Lublin oneperson Company of State Treasury. KGHM is the sixth producer of electrolytic copper and second producer of silver in the world. It also produces gold, lead, sulphuric acid and rock salt. The Company has its own ore deposits and its own 
integrated production structure with full manufacturing process from extraction to the final product. KGHM is one of the biggest Polish exporters and the biggest employer in Lower Silesia. The Capital Group comprises of, apart from the dominant entity, 83 subsidiaries.

Figure 1. The share of the biggest companies in WIG20 index (as of $21^{\text {st }}$ April, 2016)

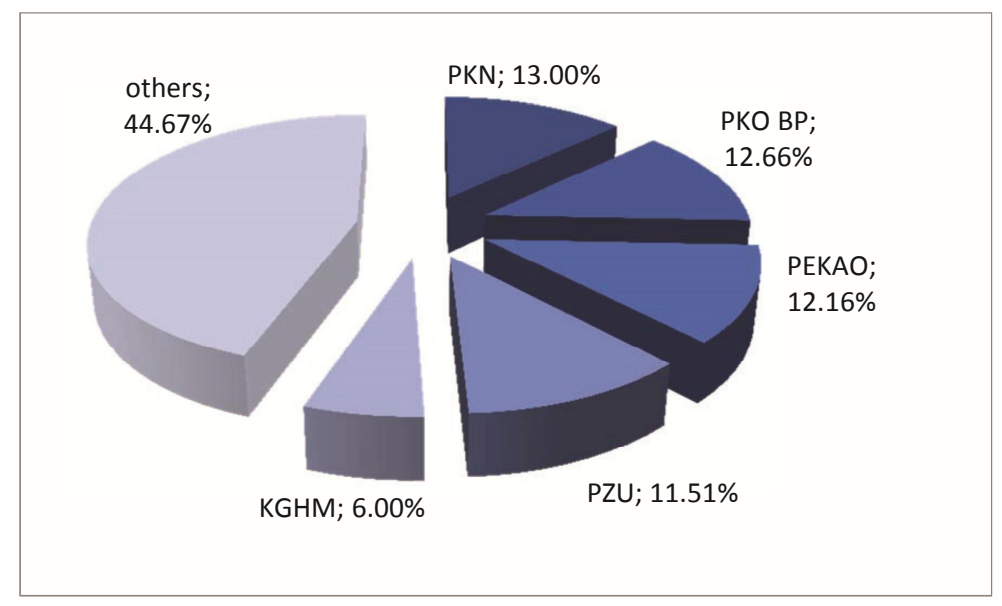

S o u r c e : own study based on Warsaw Stock Exchange (GPW).

PKN Orlen is a dominant producer and distributor of petroleum and petrochemical products in Poland. Its business consists in refining crude oil into such products as: unleaded petrol, diesel oil, fuel oil, jet fuel, also plastics and petrochemical products. The Company manages seven refineries in Poland, the Czech Republic and Lithuania. The total processing capacity of Orlen amounts to about 28 million tons of oil annually, which represents about 70 per cent of processing capacity of Polish refineries. PKN Orlen sells about 60 per cent of motor fuel wholesale in Poland, the retail sales amount to almost 40 per cent. The Company is the owner of the biggest in Central Europe network of petrol stations located in Poland, Germany, the Czech Republic and Lithuania. It also engages in offshore and onshore exploration for oil and natural gas throughout the country. One of the priorities of the Company is prospection and exploitation of gas from unconventional deposits. In its strategy, PKN Orlen aims at transforming the Company into a multi-utility company involved into the energy sector. PKN Orlen Group comprises of over 80 companies. 
Bank Pekao SA has been operating for 80 years and it is one of the biggest banks in Central Europe as well as the biggest bank in Poland in terms of market capitalization and second largest bank in terms of asset value. It is a member of UniCredit Group - one of the leading international financial institutions. Pekao is a universal commercial bank providing services to individuals and corporations. The Bank renders services to about 5 million clients, including over 250,000 small and middle-sized enterprises and over 15,000 big companies. The Capital group comprises of, apart from the Bank, an investment fund company, a pension fund, two brokerage houses and companies involved in leasing and factoring.

PKO Bank Polski is the biggest universal commercial bank in Poland. It is the leader in terms of asset value, volume of deposits, loans, the number of personal accounts and bank cards. It has the biggest in Poland sales network with almost 1,200 branches and 1,200 agencies. It offers its services mainly to retail clients, but it is also an important partner for small and middle-sized enterprises as well as big corporations. The Capital Group includes more than ten companies specialising in individual banking and finance sectors, including most of all selling financial products (pension funds), leasing products, investment fund units or electronic payment services. The Company's strategy foresees further development of the Group through strategic alliances and acquisitions.

The PZU Group is one of the biggest financial institution in Central and Eastern Europe. It comprises of such companies as: PZU (non-life insurance), PZU Życie (life insurance), PTE PZU (a pension fund) or TFI PZU (investment funds). PZU is a definite market leader in insurance in Poland.

The data for the analysis were taken from market data services. The analysis took into account recommendations issued by banks, brokerage houses and offices in the years 2010-2015 ${ }^{1}$. The analysis took into account the recommendations that included at least: the name of an instrument (a company), the name of the issuer of a recommendation, the date if its issuance, the price after issuance (reference price), the target price and the type of recommendation.

${ }^{1}$ Recommendations issued by the end of April 2015 were analysed in order to analyse the rate of return of unrealized recommendations a year after their issuance, that is by the end of April 2016. 
Figure 2. The number of recommendations made for 5 biggest companies of WIG20 index in the years 2010-2015

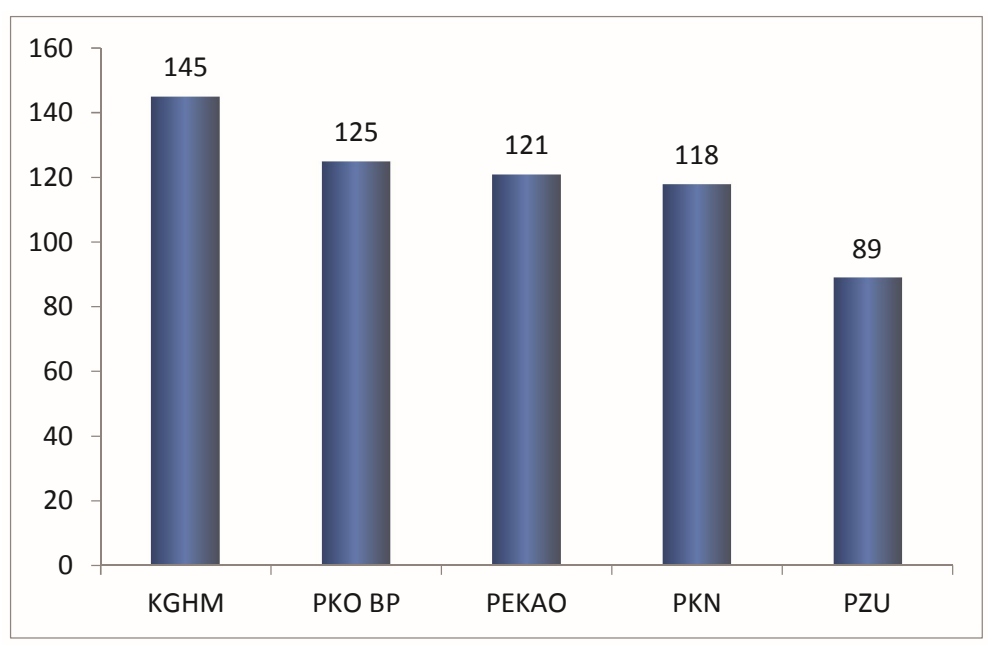

S o u r c e : own study based on stockwatch.pl and money.pl.

In the years 2010-2015 most recommendations were issued for KGHM - 145 recommendations, for PKO BP they amounted to 125 recommendations. The numbers were similar in the case of PEKAO (121 recommendations) or PKN (118 recommendations). In the case of PZU 89 recommendations were issued. The total number of the analysed recommendations in that period amounted to 598 (figure 2). The recommendations were drawn up by 40 institutions, with banks and brokerage houses and offices among them.

The biggest banks and brokerage houses such as Credit Suisse, DM m Bank, Goldman Sachs, IDMSA DM, Millennium DM, PKO BP DM, Societe General, BZ WBK DM and Wood Company prevailed among the recommending institutions (figure 3).

Taking into account neutral recommendations and the target price and its relation to the price on the day of issuance, in the case of all the analysed companies, recommendations forecasting increase in the price clearly dominated (table 3). Therefore, it confirms other authors' observations with regard to the domination of growth-promoting recommendations. 
AN ANALYSIS OF BROKERAGE RECOMMENDATIONS...

Figure 3. The number of recommendations by the issuing institutions

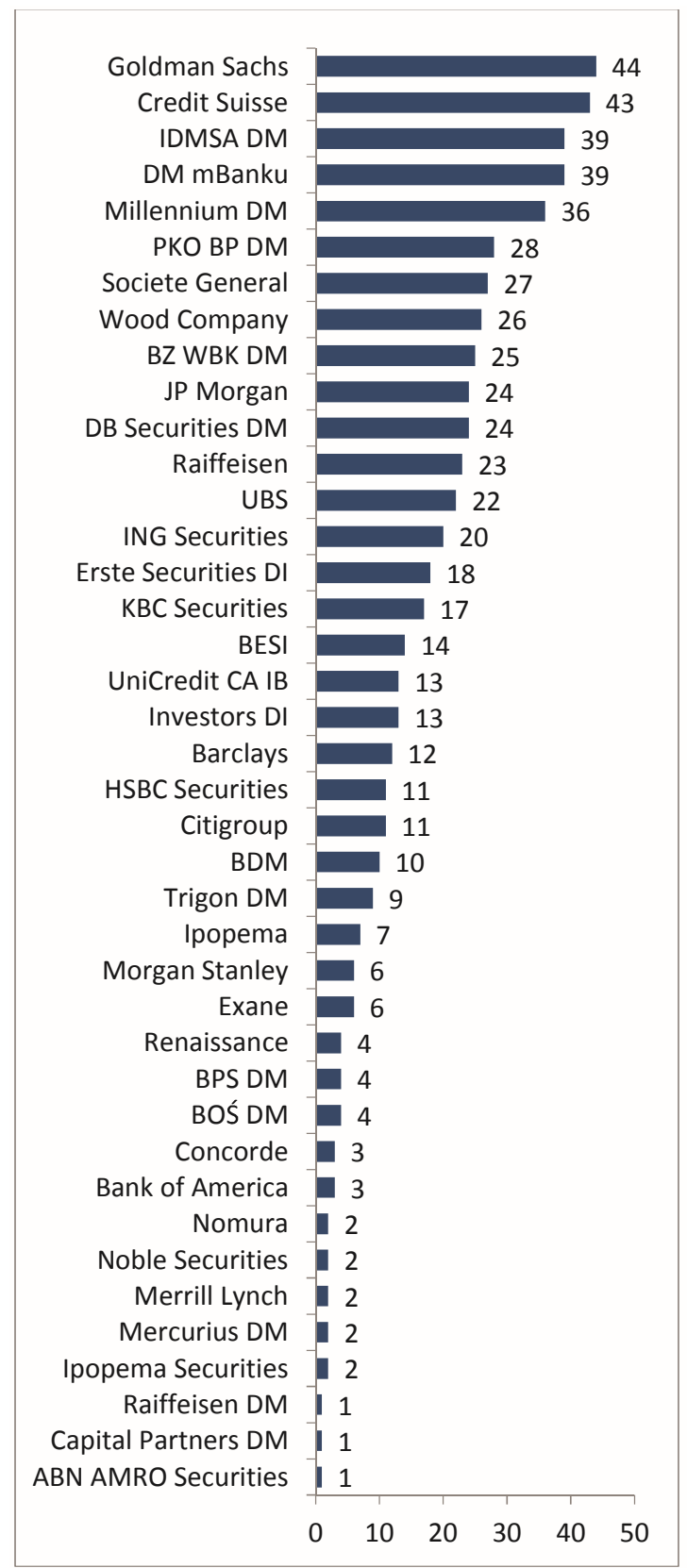

S o u r c e : own study based on stockwatch.pl and money.pl. 
When comparing the clearly indicated by the issuers trends in price changes, that is buy or sell recommendations, in the case of Pekao and PKN sell recommendations prevailed, whereas in the case of KGHM, PZU and PKO BP, buy recommendations were prevalent (table 2).

\section{THE RESEARCH METHODOLOGY AND THE COURSE OF RESEARCH PROCESS}

The analysis of recommendations will consider three aspects. Firstly, the effectiveness of recommendations, that is whether the target price has been reached and in what period of time, will be evaluated. Three periods of time will be analysed: a short period of time (up to 3 months), an mid one (from 3 to 6 months) and a long one (from 6 months to 1 year). The unrealized recommendation in that period will be considered ineffective.

Table 2. The number of issued recommendations in relation to 5 biggest WIG20 companies according to the types (2010-2015)

\begin{tabular}{|c|c|c|c|c|}
\hline \multirow{2}{*}{ Company } & \multicolumn{3}{|c|}{ Recommendations } & \multirow{2}{*}{ In total } \\
\hline & buy & neutral & sell & \\
\hline KGHM & 44 & 72 & 29 & 145 \\
\hline PEKAO & 19 & 72 & 30 & 121 \\
\hline PKN & 26 & 55 & 37 & 118 \\
\hline PZU & 42 & 45 & 2 & 89 \\
\hline PKO BP & 73 & 47 & 5 & 125 \\
\hline In total & 204 & 291 & 103 & 598 \\
\hline
\end{tabular}

S o u r c e : own study based on stockwatch.pl and money.pl.

Table 3. The number of recommendations in relation to 5 biggest WIG20 companies according to the target price forecast (2010-2015)

\begin{tabular}{|c|c|c|c|}
\hline \multirow[b]{2}{*}{ Company } & \multicolumn{2}{|c|}{ Forecast price change } & \multirow[b]{2}{*}{ In total } \\
\hline & $\begin{array}{l}\text { Target price higher than the } \\
\text { price on the day of issuing }\end{array}$ & $\begin{array}{l}\text { Target price lower than the } \\
\text { price on the day of issuing }\end{array}$ & \\
\hline KGHM & 99 & 46 & 145 \\
\hline PEKAO & 75 & 46 & 121 \\
\hline PKN & 61 & 57 & 118 \\
\hline
\end{tabular}


1. AN ANALYSIS OF BROKERAGE RECOMMENDATIONS...

Table 3. The number of recommendations..

\begin{tabular}{|c|c|c|c|}
\hline \multirow[b]{2}{*}{ Company } & \multicolumn{2}{|c|}{ Forecast price change } & \multirow[b]{2}{*}{ In total } \\
\hline & $\begin{array}{l}\text { Target price higher than the } \\
\text { price on the day of issuing }\end{array}$ & $\begin{array}{l}\text { Target price lower than the } \\
\text { price on the day of issuing }\end{array}$ & \\
\hline PZU & 77 & 12 & 89 \\
\hline PKO BP & 113 & 12 & 125 \\
\hline In total & 425 & 173 & 598 \\
\hline
\end{tabular}

S our c e : own study based on stockwatch.pl and money.pl.

In the context of the analysed recommendations, a potential rate of return will be determined.

$$
r_{p}=\frac{P_{t}-P_{c}}{P_{c}}
$$

where:

$r_{p}-$ potential rate of return,

$\mathrm{P}_{\mathrm{c}}$ - current price (market price on the day of issuing a recommendation),

$\mathrm{P}_{\mathrm{t}}$ - target price (forecast price).

If the forecast price is not reached in a given time horizon, the rate of return on this instrument will be calculated at the end of this period. If the instrument price changes like it was forecast, despite not reaching the target price, it will be considered effective, though not realized.

$$
r_{i}=\frac{P_{i}-P_{c}}{P_{i}}
$$

where:

$\mathrm{r}_{\mathrm{i}}$ - rate of return in time horizon,

$\mathrm{P}_{\mathrm{i}}$ - price at the end of the period (30 days after recommendation for short period, 60 days after recommendation for mid period and 1 year after recommendation for long period).

The rate of return will also be compared with the rate of return from socalled market portfolio, illustrated as the rate of return from WIG20 index. Socalled market premium will be determined. 


$$
m_{p}=\left(r_{i}-r_{m}\right)
$$

where:

$\mathrm{r}_{\mathrm{m}}$ - market return

Market premium indicated the difference between the realised rate of return and the rate of return of WIG20. Positive market premium means that acting upon a recommendation, a higher rate of return than the main stock index was realised. It should be taken into account that the rate of return of WIG20 index will be also determined by the behaviour of the prices of shares of the recommended company that constitutes a substantial part of WIG20 index.

If a recommendation was realized in a given period, then the potential rate of return is assumed as the rate of return in this period.

Another measure of evaluation of effectiveness will be the number of trading days from the moment of issuing a recommendation to its fulfilment (duration).

$$
d_{i}=D_{i}-D_{0}
$$

where:

$\mathrm{D}_{\mathrm{i}}$ - represents i-trading day when the recommendation is realized,

$\mathrm{D}_{0}$ - represents the day when the recommendation was issued.

The shorter the period needed to fulfil a recommendation, the better. An investor recovers the invested capital faster and then it can be allocated for other investments; an issuer of a recommendation receives a confirmation of the assumptions made earlier and it also contributes to creating and maintaining client confidence. It is also worth remembering that the shorter the time of fulfilling a recommendation, the smaller the risk of an investment.

An average daily rate of return of a realized recommendation is another measure:

- arithmetically

$$
\begin{aligned}
& r_{A}=\frac{r_{i}}{d_{i}} \\
& r_{A}=\frac{r_{i}}{d_{i}}
\end{aligned}
$$


- geometrically

$$
r_{G}=\sqrt[d_{i}]{1+r_{i}}-1
$$

where:

$\mathrm{r}_{\mathrm{A}}$ - arithmetic average rate of return in duration period,

$\mathrm{r}_{\mathrm{G}}$ - geometric average rate of return in duration period,

$\mathrm{r}_{\mathrm{i}}-$ rate of return in duration period,

$\mathrm{d}_{\mathrm{i}}$ - duration,

$\mathrm{i}=1,2, \ldots, \mathrm{n}$,

for realized recommendations $r_{i}=r_{p}$.

Using an average rate of return from a realized recommendation, it is possible to compare individual recommendations and take into account in evaluating not only the rate of return, but also the time needed for its fulfilment.

When evaluating a recommendation, the risk connected with its fulfilment is also important. For the purpose of the analysis, standard deviation of daily rates of return of investments in the period of time from the recommendation issuance to its fulfilment will be compared with standard deviation of daily rates of return in an equally long period of time back from the recommendation issuance.

$$
\partial_{i}=\sqrt{\frac{\sum_{i=0}^{n}\left(r_{i}-r_{A}\right)^{2}}{d_{i}}} ; \mathrm{i}=0,1,2, \ldots, \mathrm{n}
$$

where:

$\partial_{i}$ - standard deviation of daily returns for the period before recommendation,

$\mathrm{n}$ - number of trading days from recommendation issuance till the recommendation is realized.

Adequate standard deviation should be calculated for the period before issuance of a recommendation for the number of days represented by duration.

$$
\operatorname{prev} \partial_{i}=\sqrt{\frac{\sum_{i=-n}^{0}\left(\operatorname{prevr}_{i}-\operatorname{prevr}_{A}\right)^{2}}{d_{i}}} ; \mathrm{i}=-\mathrm{n},-(\mathrm{n}-1),-(\mathrm{n}-2), \ldots,-2,-1,0
$$


where:

prev $\partial_{i}$ - standard deviation of daily returns for the period before a recommendation,

prev $r_{i}$ - daily rate of return for days before the recommendation,

prev $r_{A}$ - average daily rate of return for the period before the recommendation.

For the purpose of evaluating the risk of investing in a recommended company, the maximum decrease of the instrument price (in the case of recommendations suggesting the price increase) or the maximum increase of the instrument price (in the case of recommendations suggesting the price decrease) in the periods of:

- recommendation fulfillment,

- within a short period,

- within an mid period,

- within a long period,

will be determined.

\section{EMPIRICAL RESULTS}

Potential rates of return of the analysed recommendations are presented in table 4. The highest rates of return could be expected from recommendations for the shares of PKO BP. In the case of all the companies, higher rates of return could be expected from recommendations forecasting the price increase than from those forecasting the price decrease (short sell).

Table 4. An average potential rate of return

\begin{tabular}{|l|c|c|c|}
\hline \hline \multirow{2}{*}{ Company } & \multicolumn{3}{|c|}{ Average potential rate of return $\left(\mathbf{a v g} \mathrm{r}_{\mathrm{p}}\right.$ ) } \\
\cline { 2 - 4 } & for all recommendations & $\begin{array}{c}\text { for recommendations } \\
\text { forecasting price increase }\end{array}$ & $\begin{array}{c}\text { for recommendations } \\
\text { forecasting price decrease }\end{array}$ \\
\hline \hline KGHM & $12.3 \%$ & $13.1 \%$ & $10.5 \%$ \\
\hline PKN & $12.5 \%$ & $14.3 \%$ & $10.5 \%$ \\
\hline PKOBP & $17.0 \%$ & $18.0 \%$ & $6.6 \%$ \\
\hline PEKAO & $9.4 \%$ & $10.4 \%$ & $7.7 \%$ \\
\hline PZU & $10.0 \%$ & $10.6 \%$ & $5.9 \%$ \\
\hline \hline
\end{tabular}

S o u r c e : own study based on carried out calculations. 
Evaluating the effectiveness of recommendations, it is worth noting that 68 per cent of them were realized, whereas in the case of the remaining 32 per cent, the target price was not reached. The analysts made the fewest mistakes when drawing up recommendations for PEKAO and KGHM, the recommendations for PKO BP proved the least effective (table 5).

Table 5. The percentage of realized and unrealized recommendations

\begin{tabular}{|l|c|c|}
\hline \hline \multicolumn{1}{|c|}{ Company } & realized recommendations & unrealized recommendations \\
\hline \hline KGHM & $78 \%$ & $22 \%$ \\
\hline PKN & $69 \%$ & $31 \%$ \\
\hline PKOBP & $39 \%$ & $61 \%$ \\
\hline PEKAO & $80 \%$ & $20 \%$ \\
\hline PZU & $73 \%$ & $27 \%$ \\
\hline In total & $68 \%$ & $32 \%$ \\
\hline \hline
\end{tabular}

S ou r c e : own study based on carried out calculations.

As many as 44 per cent of recommendations was realized in a short period of time, in the case of 12 per cent of recommendations the target price was reached in an mid period of time, whereas in the case of 12 per cent of recommendations the period of at least 6 months was necessary to reach the target price.

Table 6. Fulfilment of recommendations in relation to time horizon

\begin{tabular}{|l|c|c|c|c|c|c|c|c|c|}
\hline \hline \multirow{2}{*}{ Company } & \multicolumn{2}{|c|}{ In the short term } & \multicolumn{2}{|c|}{ In the mid term } & \multicolumn{2}{|c|}{ In the long term } & \multicolumn{2}{c|}{ Unrealized } & \multirow{2}{*}{ In total } \\
\cline { 2 - 10 } & Number & $\begin{array}{c}\text { Percen- } \\
\text { tage }\end{array}$ & Number & $\begin{array}{c}\text { Percen- } \\
\text { tage }\end{array}$ & Number & $\begin{array}{c}\text { Percen- } \\
\text { tage }\end{array}$ & Number & $\begin{array}{c}\text { Percen- } \\
\text { tage }\end{array}$ & (n) \\
\hline \hline KGHM & 87 & $60 \%$ & 14 & $10 \%$ & 12 & $8 \%$ & 32 & $22 \%$ & 145 \\
\hline PKN & 46 & $39 \%$ & 16 & $14 \%$ & 20 & $17 \%$ & 36 & $31 \%$ & 118 \\
\hline PKOBP & 27 & $22 \%$ & 8 & $6 \%$ & 14 & $11 \%$ & 76 & $61 \%$ & 125 \\
\hline PEKAO & 64 & $53 \%$ & 16 & $13 \%$ & 17 & $14 \%$ & 24 & $20 \%$ & 121 \\
\hline PZU & 42 & $47 \%$ & 15 & $17 \%$ & 8 & $9 \%$ & 24 & $27 \%$ & 89 \\
\hline In total & $\mathbf{2 6 6}$ & $\mathbf{4 4 \%}$ & $\mathbf{6 9}$ & $\mathbf{1 2} \%$ & $\mathbf{7 1}$ & $\mathbf{1 2} \%$ & $\mathbf{1 9 2}$ & $\mathbf{3 2 \%}$ & $\mathbf{5 9 8}$ \\
\hline \hline
\end{tabular}

S o u r c e : own study based on carried out calculations. 
Analysing the realized recommendations, for 14 per cent of the cases, despite reaching the target price, WIG20 index noted a higher increase compared with the corresponding period. It was therefore possible to find an alternative investment on the market that would have brought a higher rate of return (table 7).

Table 7. The number of realized recommendations but with a lower rate of return than WIG20 index compared with the corresponding period

\begin{tabular}{|l|c|c|}
\hline \hline \multicolumn{1}{|c|}{ Company } & Number & The share in realized recommendations \\
\hline \hline KGHM & 11 & $10 \%$ \\
\hline PKN & 7 & $9 \%$ \\
\hline PKOBP & 11 & $22 \%$ \\
\hline PEKAO & 16 & $16 \%$ \\
\hline PZU & 11 & $17 \%$ \\
\hline In total & 56 & $14 \%$ \\
\hline \hline
\end{tabular}

S o u r c e : own study based on carried out calculations.

The target price was reached fastest in the case of the recommendations for KGHM (a recommendation was realized on average after 47 days), the investors using the recommendations for PKO BP needed the most time - on average 85 days (table 8).

Table 8. The average number of trading days needed for reaching the target price for realized recommendations

\begin{tabular}{|l|c|}
\hline \hline \multicolumn{1}{|c|}{ Company } & Average number of days (avg $d_{i}$ ) \\
\hline \hline KGHM & 47 \\
\hline PKN & 74 \\
\hline PKOBP & 85 \\
\hline PEKAO & 58 \\
\hline PZU & 58 \\
\hline \hline
\end{tabular}

S our c e : own study based on carried out calculations.

The investors carrying transactions in shares of PKN (10.86 per cent) and KGHM (10.78 per cent) reached the highest rate of return from the realized 
recommendations, an average rate of return was by about 7 percentage points higher than a change of WIG20 index in a corresponding period of time (table 9).

Table 9. An average rate of return for realized recommendations

\begin{tabular}{|l|c|c|}
\hline \hline Company & $\begin{array}{c}\text { An average rate of return } \\
\text { of a realized recommendation }\end{array}$ & $\begin{array}{c}\text { An average difference between a rate of return } \\
\text { of a realized recommendation and WIG20 rate of return (avg } \mathbf{m}_{\mathrm{p}} \text { ) }\end{array}$ \\
\hline \hline KGHM & $10.78 \%$ & $6.96 \%$ \\
\hline PKN & $10.86 \%$ & $7.09 \%$ \\
\hline PKOBP & $9.88 \%$ & $5.59 \%$ \\
\hline PEKAO & $7.15 \%$ & $3.29 \%$ \\
\hline PZU & $7.95 \%$ & $5.28 \%$ \\
\hline \hline
\end{tabular}

S o u r c e : own study based on carried out calculations.

Comparing the rate of return for realized recommendations with the number of trading days needed for their fulfilment, it can be stated that in a short period of time the highest rate of return on a trading day was noted for investments in the shares of KGHM. In an mid period of time, the recommendations realized for PEKAO proved the most effective, but in a long period of time those for PKN did (table 10).

Table 10. The rate of return for a realized recommendation on a trading day

\begin{tabular}{|l|c|c|c|}
\hline \hline \multicolumn{1}{|c|}{ Company } & A short period & An mid period & A long period \\
\hline \hline KGHM & $0.6406 \%$ & $0.1498 \%$ & $0.0125 \%$ \\
\hline PKN & $0.4709 \%$ & $0.1253 \%$ & $0.0277 \%$ \\
\hline PKOBP & $0.3199 \%$ & $0.1782 \%$ & $0.0024 \%$ \\
\hline PEKAO & $0.3673 \%$ & $0.1842 \%$ & $0.0061 \%$ \\
\hline PZU & $0.3476 \%$ & $0.1764 \%$ & $0.0235 \%$ \\
\hline \hline
\end{tabular}

S o u r c e : own study based on carried out calculations.

In the analysis, the risk of investments based on recommendations was also assessed. It turns out that in a short period of time, an average rate of return of unrealized recommendations was negative for all the companies. This proves evidence that not reaching the target price within 3 months from issuing a rec- 
ommendation, the share prices moved in the opposite direction. 6 months after issuing the recommendations, an average rate of return for unrealized recommendations was also negative. The same refers to the long period. In general, not fulfilling recommendation results in losses for investor (table 11).

Table 11. An average rate of return of unrealized recommendations

\begin{tabular}{|l|c|c|c|c|c|c|}
\hline \hline Company & $\begin{array}{c}\text { Recommendations } \\
\text { unrealized } \\
\text { in a short period }\end{array}$ & Number & $\begin{array}{c}\text { Recommendations } \\
\text { unrealized } \\
\text { in an mid period }\end{array}$ & Number & $\begin{array}{c}\text { Recommendations } \\
\text { unrealized } \\
\text { in a long period }\end{array}$ & Number \\
\hline \hline KGHM & $-5.9 \%$ & 58 & $-11.5 \%$ & 44 & $-19.1 \%$ & 32 \\
\hline PKN & $-4.1 \%$ & 72 & $-10.0 \%$ & 56 & $-15.8 \%$ & 36 \\
\hline PKOBP & $-1.9 \%$ & 98 & $-2.7 \%$ & 90 & $-10.6 \%$ & 76 \\
\hline PEKAO & $-1.0 \%$ & 57 & $-0.6 \%$ & 41 & $-1.6 \%$ & 24 \\
\hline PZU & $-2.1 \%$ & 47 & $-4.5 \%$ & 32 & $-8.7 \%$ & 24 \\
\hline \hline
\end{tabular}

S o u r c e : own study based on carried out calculations.

The maximum loss from an unrealized individual recommendation for a given company, presented in table 12., is also worth noting.

Table 12. The biggest loss from unrealized recommendations

\begin{tabular}{|l|c|c|c|}
\hline \hline \multicolumn{1}{|c|}{ Comany } & A short period & An mid period & A long period \\
\hline \hline KGHM & $-16.62 \%$ & $-45.95 \%$ & $-74.00 \%$ \\
\hline PKN & $-4.44 \%$ & $-18.07 \%$ & $-52.61 \%$ \\
\hline PKOBP & $-2.57 \%$ & $-11.84 \%$ & $-31.97 \%$ \\
\hline PEKAO & $-10.96 \%$ & $-10.92 \%$ & $-27.62 \%$ \\
\hline PZU & $-10.08 \%$ & $-6.49 \%$ & $-19.21 \%$ \\
\hline \hline
\end{tabular}

S ou r c e : own study based on carried out calculations.

The risk estimated with standard deviation of daily rates of return of the shares of companies whose recommendations were realized was analysed. It should be noted that in most cases the investment risk lowered during fulfilling of the recommendations compared with the corresponding period of time before the issuance. Average of the differences of standard deviations of rates of 
return in the time of the fulfilment of a recommendation and the period before issuing the recommendation in the case of all the companies is negative, which indicates a lower risk of investment (table 13).

Table 13. The investment risk in the duration of realized recommendations compared with the risk in the corresponding period before issuing recommendations ${ }^{*}$

\begin{tabular}{|l|c|c|c|}
\hline \hline Company & $\begin{array}{c}\text { Average of the difference } \\
\boldsymbol{\partial}_{\boldsymbol{i}}-\text { prev }_{\boldsymbol{i}}\end{array}$ & $\begin{array}{c}\text { Number of recommendations } \\
\text { for which the risk lowered }\end{array}$ & $\begin{array}{c}\text { Number of recommendations } \\
\text { for which the risk grew }\end{array}$ \\
\hline \hline KGHM & -0.00385 & 74 & 39 \\
\hline PKN & -0.00153 & 54 & 19 \\
\hline PKOBP & -0.00041 & 30 & 43 \\
\hline PEKAO & -0.00115 & 54 & 28 \\
\hline PZU & -0.00116 & 38 & 28 \\
\hline \hline
\end{tabular}

* Investment risk measured with standard deviation of daily rates of return.

S o u r c e : own study based on carried out calculations.

\section{CONCLUSION}

The conducted analysis concerned 5 companies which constituted the subject of recommendations. It is recommended to expand the research based on a bigger number of companies and a longer time of analysis in the future. The analysis of the effectiveness of recommendations from the point of view of the issuing entity can also lead to interesting conclusions. The carried out research leads to the conclusion that apart from the analysis of the rate of return or of the fact of fulfilling a recommendation, attention should be given to the risk connected with an investment. While standard deviation of daily rates of return can lead to the conclusion that during investment realisation the variations in the daily rates of return were smaller than in the period before issuing the recommendations, it concerned only the realized recommendations. The losses from unrealized recommendations must not be forgotten. Stock recommendations may constitute only one of the tools for taking an investment decision. Others like, for instance, a technical analysis and fundamental analysis on the micro- and macroeconomic level should be taken into account as well. 


\section{REFERENCES}

Adamczyk, C. (2010). Analitycy pomylili się najbardziej w ocenie banków. Gazeta Giełdy Parkiet, www.parkiet. com/artykul/960057.html (accessed: 03.07.2016).

Barber, B., Lehavy, R., McNichols, M., \& Trueman, B. (2001). Can Investors Profit from the Prophets? Security Analyst Recommendations and Stock Returns. The Journal of Finance, 56(2), April, pp. 531-563. http://dx.doi.org/10.1111/0022-1082.00336.

Biedrzyński, R. (2008). Wycena w rekomendacjach sporządzanych przez biura maklerskie a cena rynkowa spółek notowanych na Giełdzie Papierów Wartościowych w Warszawie, http://biedrzynski-consulting.home.pl/ (accessed: 20.04.2016).

Boczkowski, A. (2008). Sprawdziliśmy 130 rekomendacji. Puls Biznesu, www. pb.pl/1275391,27750,sprawdzilis my-130-rekomendacji (accessed: 03.07.2016).

Cowles, A. (1933). Can Stock Market Forecasters Forecast? Econometrica, 1(3), July 1933, pp. 309-324. http://dx.doi.org/10.2307/1907042.

Czyżycki, R., Klóska, R. (2010). Rekomendacje giełdowe jako źródło wiedzy dla inwestora indywidualnego. MEK 2010 Company Processes and Market Requirements, Hradec Kralove, Czech Republic, pp. 2371-2378.

Dechow, P., Kothari, S., \& Watts, R. (1998). The relation between earnings and cash flows. Journal of Accounting and Economics, 25, August, pp. 133-168. http://dx.doi. org/10.1016/S0165-4101(98)00020-2.

Ertimur, Y., Zhang, F., \& Muslu, V. (2011). Why Are Recommendations Optimistic? Evidence from Analysts' Coverage Initiations. Review of Accounting Studies, 16(4), December 2011, pp. 679-718.

Jegadeesh, N., Kim, J., Krische, S., \& Lee, C. (2004). Analyzing the analyst: When do recommendations add value? Journal of Finance, 59(3), June, pp. 1083-1124. http:// dx.doi.org/10.1111/j.1540-6261.2004.00657.x.

Konopko, Ł., Kokolus, E. (2012). Sprawdzalność rekomendacji domów maklerskich, http://wiadomosci.stockwatch.pl/raport-sprawdzalnosc-rekomendacji-domowmaklerskich,strategie-inwestycyjne,23802 (accessed: 20.04.2016).

Kowalke, K. (2012), Ocena przydatności rekomendacji giełdowych opartych na metodzie DCF na przykładzie spółek budowlanych. In K. Jajuga, W. Ronka-Chmielowiec (Ed.), Inwestycje finansowe i ubezpieczenia - tendencje światowe a rynek polski: (pp. 103-112). Wrocław: Wydawnictwo Uniwersytetu Ekonomicznego we Wrocławiu.

Loh, R.K., \& Mian, G.M. (2006). Do Accurate Earnings Forecasts Facilitate Superior Investment Recommendations? Journal of Financial Economics, 80(2), May, pp. 455-483. http://dx.doi.org/10.1016/j.jfineco.2005.03.009.

Papakroni, J. (2012). The dispersion anomaly and analyst recommendations, working paper, http://www.be.wvu.edu/phd_economics/cvs/Papakroni_Jobmarket.pdf (accessed: 20.04.2016).

Prusak, B. (2015). Wielokryterialna analiza rekomendacji giełdowych. Warszawa: CeDeWu. 
AN ANALYSIS OF BROKERAGE RECOMMENDATIONS...

Rozporządzenie ministra finansów z dnia 19 października 2005 r. w sprawie informacji stanowiących rekomendacje dotyczące instrumentów finansowych, ich emitentów lub wystawców (Dz.U. Nr 206, poz. 1715 z poźn. zm.) [Act of Law in Polish].

Ryan, P., Taffler, R.J. (2006). Do brokerage houses add value? The market impact of UK sell-side analyst recommendation changes. The British Accounting Review, 34, pp. 371-386. https://doi.org/10.1016/j.bar.2006.07.015.

Womack, K. (1996). Do brokerage analysts' recommendations have investment value? The Journal of Finance, 51(1), March, pp. 137-167. https://doi.org/10.1111/j.1540 -6261.1996.tb05205.x.

Zaremba, A., Konieczka, P. (2014). Skuteczność rekomendacji maklerskich na polskim rynku akcji. Zeszyty Naukowe Uniwersytetu Szczecińskiego, 803, Finanse, Rynki Finansowe, Ubezpieczenia 66, pp. 573-581. 
